\title{
HOUSING MARKET CYCLES IN THE CONTEXT OF BUSINESS CYCLES
}

\author{
Konrad Żelazowski, PhD \\ Faculty of Economics and Sociology \\ University of Lodz \\ e-mail:kzelazowski@uni.lodz.pl
}

\begin{abstract}
Housing markets as well as the overall economy develop unevenly. Business cycles are the result of the diverse dynamics of their development. The housing market, as one of the components of economic systems, is influenced by business cycles, at the same time affecting them as well. It should be noted, however, that the special nature of this market may determine a different course of housing market cycles in comparison with changes in business cycles.

The aim of the paper is to identify similarities and differences in the shaping of the housing market cycle and the business cycle. The analysis will be conducted on the basis of experience from the Polish market and selected Western markets.
\end{abstract}

Key words: housing market, housing market cycles, business cycle.

JEL Classification: E30, E32, R31.

Citation: Żelazowski K., 2017, Housing Market Cycles in the Context of Business Cycles, Real Estate Management and Valuation, vol. 25, no. 3, pp. 05-14.

DOI: 10.1515/remav-2017-0017

\section{Introduction}

The housing market is an important, yet special, sector of the national economy. Its importance is derived from two main factors: the size of the housing market and the functions that residential properties perform. In mature market economies, the share of the widely understood housing sector (including housing management, housing financing and housing construction) in gross value added is an average of $20 \%$ (LAMA, DENIS 2014, p. 5), whereas the scale of investment expenditure on housing stands at $4 \%-6 \%$ of the national GDP (BANDT et al. 2010, p. 71).

Residential properties additionally perform a number of important socio-economic functions. They meet the most basic needs of having a place to call home and a sense of security, as well as the needs of a higher order, such as the possibility of forming social ties or meeting the needs of self-realisation. Adequate housing is a measure of a decent life, and its absence is one of the main causes of so-called social exclusion (MICKIEWICZ, WENCEL 2013, p. 2).

Residential properties are also an important component of household assets (compare: Table 1). The purchase of a dwelling is the biggest investment in the case of many households, affecting other aspects of their functioning, including decisions on starting a family, labour market mobility and consumer spending, e.g.: in the framework of the wealth effect.

The size of the housing market and its strong links with other sectors of the economy constitute a premise for the formulation of the hypothesis on a vital interdependence of the housing market cycle and the business cycle. The paper is an attempt to empirically verify the course of housing market cycles in relation to cyclical changes in the overall economy. An analysis of their synchronisation will also be carried out based on housing market cycles and business cycles in the Polish market and selected Western markets. 
The importance of residential properties in household assets

\begin{tabular}{lrcccc}
\hline \multirow{2}{*}{ Country } & \multicolumn{5}{c}{ Share of residential property in total assets (\%) } \\
\cline { 2 - 6 } & $\mathbf{1 9 9 5}$ & $\mathbf{2 0 0 0}$ & $\mathbf{2 0 0 5}$ & $\mathbf{2 0 1 0}$ & $\mathbf{2 0 1 4}$ \\
\hline USA & $44,8 \%$ & $43,5 \%$ & $50,7 \%$ & $38,4 \%$ & $37,5 \%$ \\
\hline UK & $47,7 \%$ & $50,3 \%$ & $59,6 \%$ & $60,2 \%$ & $59,0 \%$ \\
\hline Switzerland & $\mathrm{n} / \mathrm{a}$ & $57,4 \%$ & $56,1 \%$ & $60,0 \%$ & $62,4 \%$ \\
\hline Germany & $52,0 \%$ & $47,4 \%$ & $44,4 \%$ & $45,7 \%$ & $\mathrm{n} / \mathrm{a}$ \\
\hline Holland & $31,5 \%$ & $25,1 \%$ & $26,6 \%$ & $28,4 \%$ & $26,3 \%$ \\
\hline Finland & $\mathrm{n} / \mathrm{a}$ & $78,3 \%$ & $74,0 \%$ & $76,3 \%$ & $77,2 \%$ \\
\hline Italy & $\mathrm{n} / \mathrm{a}$ & $64,6 \%$ & $69,0 \%$ & $72,9 \%$ & $73,3 \%$ \\
\hline Poland & $\mathrm{n} / \mathrm{a}$ & $79,8 \% *$ & $66,6 \%$ & $60,4 \%$ & $\mathrm{n} / \mathrm{a}$ \\
\hline *data for 2002. & & & & &
\end{tabular}

Source: the author's own compilation based on the OECD data.

\section{Literature review}

\subsection{Housing market cycles}

The housing market, similarly to other markets as well as the overall economy, develops unevenly. The analysis of changes in the activity of actors in the housing market and the dynamics of its main aggregates allows the identification of specific components of the path of its development (TROJANEK 2008a, pp. 68-69; SОВCZYK 2000, p. 335):

- Trend - representing the long-term development trend of the housing market.

- Cyclical fluctuations - fluctuations in the levels of a given phenomenon occurring with variable regularity due to changes in economic conditions.

- Seasonal fluctuations - regularly repeated on an annual basis fluctuations of economic processes which are a result of the impact of natural factors (mainly the change of seasons), as well as institutional or legal factors on the course of these processes.

- Random fluctuations - irregular fluctuations in economic activity that are a consequence of the influence of random, incidental factors.

The manner in which business cycles are defined is paramount in the process of their identification. Traditionally, business cycles are defined as "fluctuations occurring in aggregates representing economic activity of nations that organise their production mainly through enterprises" (SKRZYPCZYŃSKI 2010, p. 12). According to the classical definition, the business cycle consists of four phases: crisis, stagnation, recovery and expansion. Identification of individual phases is associated with the assessment of the dynamics of selected processes and economic variables in absolute terms (KONOPCZAK 2009).

Nowadays cycles are increasingly defined as recurring oscillations of selected economic aggregates along their long-term economic growth path (trend) (KUCHARSKA-STASIAK 2008, p. 31). In the course of the cycle two basic phases are determined: recovery - growth in economic activity - and recession - a decrease in economic activity relative to the long-term trend.

Based on the above-presented definitions of the business cycle, a classical housing market cycle and a modern one can be distinguished (BRACKE 2013). In the classical approach, the housing market cycle is therefore defined as "fluctuations in activity of this market (measured by changes in residential property prices, the number of transactions or residential investments undertaken) expressed in absolute terms through levels of the variable or through the growth rate of the variable" (Lis 2015, p. 38). In the modern approach, the housing market cycle is characterised as: "demand, supply, real estate prices and real estate stock tendencies to fluctuate around their long-term trends or average values" (KUCHARSKA-STASIAK 2006, p. 104). 
Taking into account the specific nature of the housing market, in particular the differences in the price elasticity of demand and supply, as well as time-consumption of processes of investment in housing, it is difficult to talk about one universal housing market cycle. In the literature, two basic types of housing market cycle are most frequently mentioned (KUCHARSKA-STASIAK et al. 2012, pp. 3435):

- Demand cycle - a cycle determined by changes in demand, more strongly correlated with the economic situation, with an average duration of 4-5 years.

- Supply cycle - a cycle driven by changes in the activity of the supply side of the market, to a lesser extent linked to the overall economic situation, with a longer duration of approx. 10 years.

The type of variable adopted in the analysis as a barometer of housing market cycles is a supplementary criterion allowing a secondary division of housing market cycles into:

- Quantitative cycles - identified on the basis of economic parameters expressed in natural units (e.g.: items), for instance, based on the number of transactions, or the number of dwellings completed.

- Volume cycles - identified using volumes of the most significant variables of the housing market, e.g.: the value of residential real estate transactions, values of started or completed investments in residential real estate.

- Price cycles - identified on the basis of changes in residential real estate prices and rents.

\subsection{The housing market cycle and the business cycle}

Theoretical and empirical studies on the issue of the functioning of housing markets confirm the important role of macroeconomic conditions in shaping their cyclic development. The housing market and the economy interact with each other, and the channels of their mutual interactions are both direct and indirect. The phase of expansion in the housing market is usually a consequence of economic recovery (compare: Figure. 1). Economic growth and the accompanying increase in employment and wages are an incentive for households to improve their housing conditions. In the phase of economic prosperity, demand for real estate can be further stimulated by cheap and accessible mortgages. In the conditions of rapidly growing demand, the housing market experiences growth in real estate prices, which in turn induces developers to further engage in the construction market. In the initial phase, the construction boom allows to maintain the period of prosperity. However, when subsequent investments are completed, the increasing housing supply limits the demand pressure present in the market. The housing market cycle reaches a turning point, after which a decline in trading activity in the market as well as the scale of lending, and consequently a fall in prices are observed. The crisis in the housing market deepens recession observed throughout the overall economy.

Interactions between the housing market and the economy may also have a more subtle, indirect nature. As part of the wealth effect, changes in the value of residential real estate have an impact on the level of household consumption expenditures. With the increase in the value of real estate assets, households are willing to increase their own consumption, whereas a fall in the value of real estate owned limits their spending in this area. Empirical studies emphasise that the real estate wealth effect is stronger and longer lasting than the wealth effect caused by financial assets (TAKHTAMANOVA, SIERMINSKA, 2008).

Real estate assets are also common as collateral for bank loans. Changes in the value of real estate, however, have an impact not only on the security of the banking sector but also determine the creditworthiness of property owners. Higher amounts of credit available to households during periods of housing boom stimulate their consumer spending and investment expenditures (BELSKY, PRAKKEN 2004).

Another area of transfer of cyclical impulses from the housing market to the economy is a rapidly growing segment of financial products based on real estate. As the experience of the recent global economic crisis shows, the expansion of the market of securitisation transactions carried out on the basis of mortgages along with the accompanying credit default swap contracts and the development of the derivatives market based on real estate indices can become a source of deep crisis not only in real estate markets but also in the overall economy. 
Real Economy

Real estate market

Financial sector

Economic

Economic boom

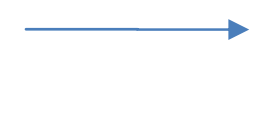

Increased property demand<smiles>C1CCCCC1</smiles>

Supply shortages

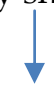

Rising rent and prices<smiles>C=CCCC</smiles>

Building boom

Economic downturn

Increased supply

Slackening demand

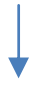

Falling rent and prices

Recession

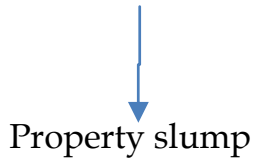

Credit expansion

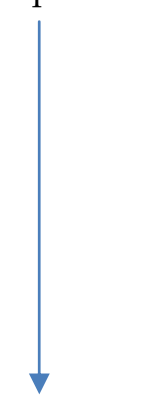

Credit boom

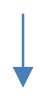

Rising interes rates

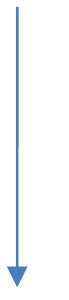

Credit squeeze

Fig. 1. The mechanism of the housing market cycle. Source: BARRAS (1994).

Despite a number of identified areas of interdependence between the economy and the housing market, there are no clear indications as to the direction of the relationship between business cycles and housing market cycles. These relationships can be represented as three different concepts:

1. The first concept assumes that due to the importance of the housing market in the national economy, changes in the activity of this market have a significant impact on the course of the business cycle. The housing market can thus induce fluctuations in the overall economy through a number of channels. Recognising the housing market as one of the driving forces of business cycles, it should be assumed that the housing market cycle ought to precede the business cycle (LEAMER 2007; GHENT, OWYANG 2009).

2. The second concept assumes that the housing market only reflects changes in macroeconomic conditions. Changes and fluctuations observed in the housing market are therefore a consequence of the processes taking place in the overall economy (CATTE et al. 2004). In this approach, the housing market cycle may occur with some delay in relation to the business cycle, or may be concurrent with it.

3. The third concept assumes that housing market cycles and business cycles are not closely related. Different phases of the two cycles may be synchronised with one another but do not have to be. Fluctuations in the housing market do not need to be necessarily accompanied by business cycle fluctuations in the same direction, and overall economy fluctuations do not always have to induce equally strong changes in the housing sector. As emphasised by Prof. E. Kucharska-Stasiak: "real estate cycles can be more volatile and longer than business cycles - but they can also be forced and shorter. Forces within the real estate sector are the source of these differences." (KUCHARSKA-STASIAK et al. 2012, p. 37).

\section{Data and methods}

Verification of the course, interdependences and synchronisation of housing market cycles and business cycles was conducted on the basis of data on the Polish economy, as well as the economies of Germany, France, Great Britain and Ireland. The price index of residential property for the secondary 
market was adopted in the study as the reflection of the housing market cycle and the GDP index for the business cycle. Table 2 contains detailed information regarding the time series used in the study.

Characteristics of data included in the research procedure

Table 2

\begin{tabular}{|c|c|c|c|c|}
\hline Country & Variable & Time interval & Specificity of time series & Source of data \\
\hline \multirow[t]{2}{*}{ Poland } & $\begin{array}{l}\text { The price of } 1 \mathrm{~m} 2 \text { of usable area } \\
\text { in real terms } \\
\text { (3Q2005 prices) }\end{array}$ & 3Q2005-3Q2015 & $\begin{array}{l}\text { RPI - single base } \text { index } \\
(3 Q \text { 2005 }=100)\end{array}$ & $\begin{array}{l}\text { PKO BP S.A., GUS } \\
\text { (Central Statistical } \\
\text { Office of Poland) }\end{array}$ \\
\hline & Real GDP (3Q2005 prices) & 3Q2005-3Q2015 & $\begin{array}{l}\text { GDP - single base index } \\
(3 Q \text { 2005 }=100)\end{array}$ & $\begin{array}{l}\text { GUS } \\
\text { Statistical Office of } \\
\text { Poland) }\end{array}$ \\
\hline \multirow{2}{*}{$\begin{array}{l}\text { Germany } \\
\text { France } \\
\text { UK } \\
\text { Ireland }\end{array}$} & $\begin{array}{l}\text { The price of } 1 \mathrm{~m} 2 \text { of usable area } \\
\text { in real terms ( } 2010 \text { prices) }\end{array}$ & 1Q1971-4Q2013 & $\begin{array}{l}\text { RPI - single base index } \\
(1 Q \text { 1971 }=100)\end{array}$ & $\begin{array}{l}\text { OECD Housing } \\
\text { Prices database }\end{array}$ \\
\hline & Real GDP (2010 prices) & 1Q1971-4Q2013 & $\begin{array}{l}\text { GDP - single base index } \\
(1 Q \text { 1971=100) }\end{array}$ & $\begin{array}{l}\text { OECD Quarterly } \\
\text { National Accounts }\end{array}$ \\
\hline
\end{tabular}

Source: the author's own compilation.

The time series of the presented variables were seasonally adjusted using the X-12-ARIMA method. In the next stage, Hodrick - Prescott (HP) and Baxter-King (BK) frequency filters were used in order to isolate a cyclic component. The Hodrick - Prescott filter presented by the authors in 1997 is a high-pass filter. Its nature lies in the elimination of high-frequency fluctuations from the series, leaving the long-term trend (HODRICK, PRESCOTT 1997). Comparing the original time series and the estimated long-term trend, it is possible to isolate a cyclical component (UlRICHS et al. 2014, p. 11). The Baxter-King filter (Baxter, King 1999) proposed in 1999 is a bandpass filter which allows to eliminate high and low frequency components from the time series (random fluctuations and the trend), thus leaving a cyclic component (UlRICHS et al. 2014, p. 12).

In the case of the Polish economy, due to the significantly shorter research horizon, the analysed cycles were isolated only on the basis of the Hodrick - Prescott filter (the application of the BaxterKing filter would have involved an additional shortening of the time series).

Turning points in the course of cycles were identified using the Harding-Pagan algorithm. In the first stage of the procedure local minima and maxima were identified using two-sided 4-quarter windows:

- Peak at $\mathrm{t}:\left(\mathrm{X}_{\mathrm{t}-4}, \ldots \mathrm{X}_{\mathrm{t}-1}<\mathrm{X}_{\mathrm{t}}>\mathrm{X}_{\mathrm{t}+1}, \ldots \mathrm{X}_{\mathrm{t}+4}\right)$.

- Trough at $\mathrm{t}:\left(\mathrm{X}_{\mathrm{t}-4}, \ldots \mathrm{X}_{\mathrm{t}-1}>\mathrm{X}_{\mathrm{t}}<\mathrm{X}_{\mathrm{t}+1}, \ldots \mathrm{X}_{\mathrm{t}+4}\right)$.

The second stage verified alternation of local minima and maxima occurrence. When consecutive minima (maxima) took place one after another, a quarter with the lowest (highest) value of cyclical component was selected as the turning point in the course of the cycle (BRACKE 2013). In addition, it was assumed that the minimum housing cycle length was 8 quarters, while the minimum length of a single cycle phase (upward or downward), was 4 quarters.

In order to verify the degree of correlation and synchronisation of the analysed cycles, two measures were used: cross-correlation coefficient and concordance index in the following formula (AKIMOV 2015):

$$
\Sigma I=\frac{1}{T}\left(\sum_{t=1}^{T} S_{f t} \cdot S_{t t}+\Sigma_{t=1}^{T}\left(1-S_{f t}\right) \cdot\left(1-S_{t i}\right)\right)
$$

where:

\section{Cl- concordance index}

$S_{j t}$ - cycle phase in period $t$ for market $j$ (takes on the value of 1 in the growth phase and 0 in the decline phase) 
$S_{\text {it }}$ - cycle phase in period $t$ for market $i$ (takes on the value of 1 in the growth phase and 0 in the decline phase)

$\mathrm{T}$ - number of analysed periods.

The concordance index determines the number of periods in which the analysed cycles are in the same phase (in the growth phase or the decline phase) in the percentage terms. At full cycle synchronisation, the index takes on the value of $100 \%$, in the absence of synchronisation the value of 0 (DOMAŃSKA, SERWA 2014, p. 33).

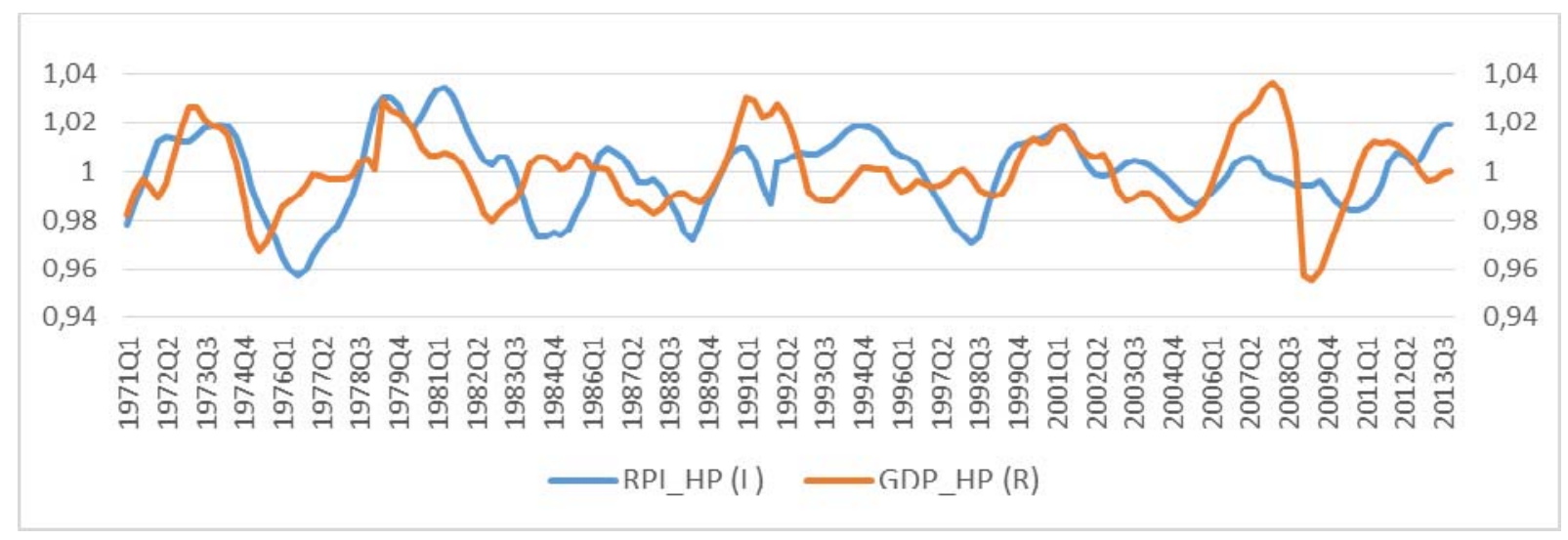

Fig. 1a. Housing market cycles and business cycles in Germany. Source: the author's own compilation.

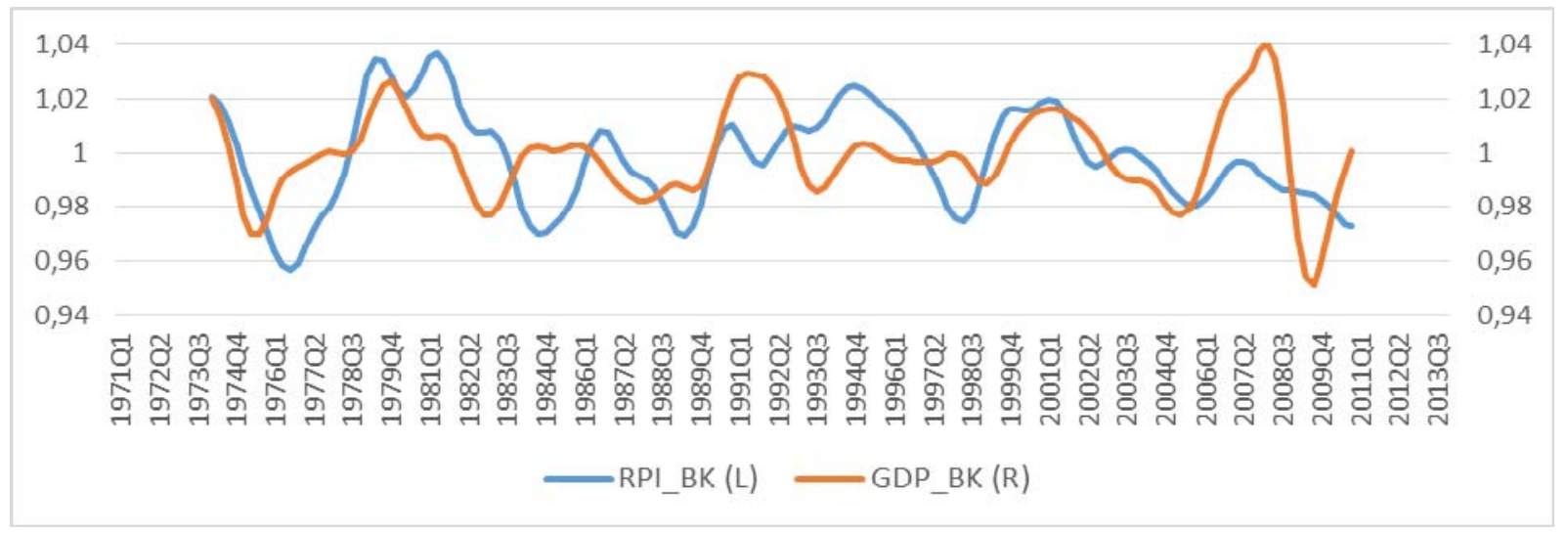

Fig. 1b. Housing market cycles and business cycles in Germany. Source: the author's own compilation.

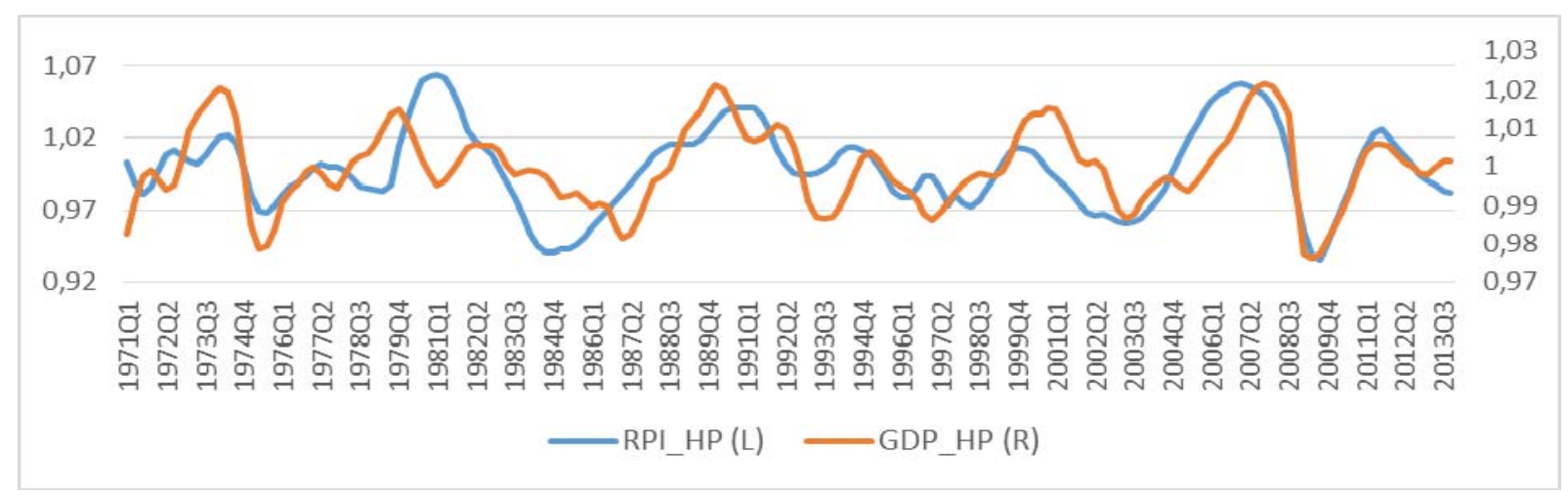

Fig. 2a. Housing market cycles and business cycles in France. Source: the author's own compilation. 


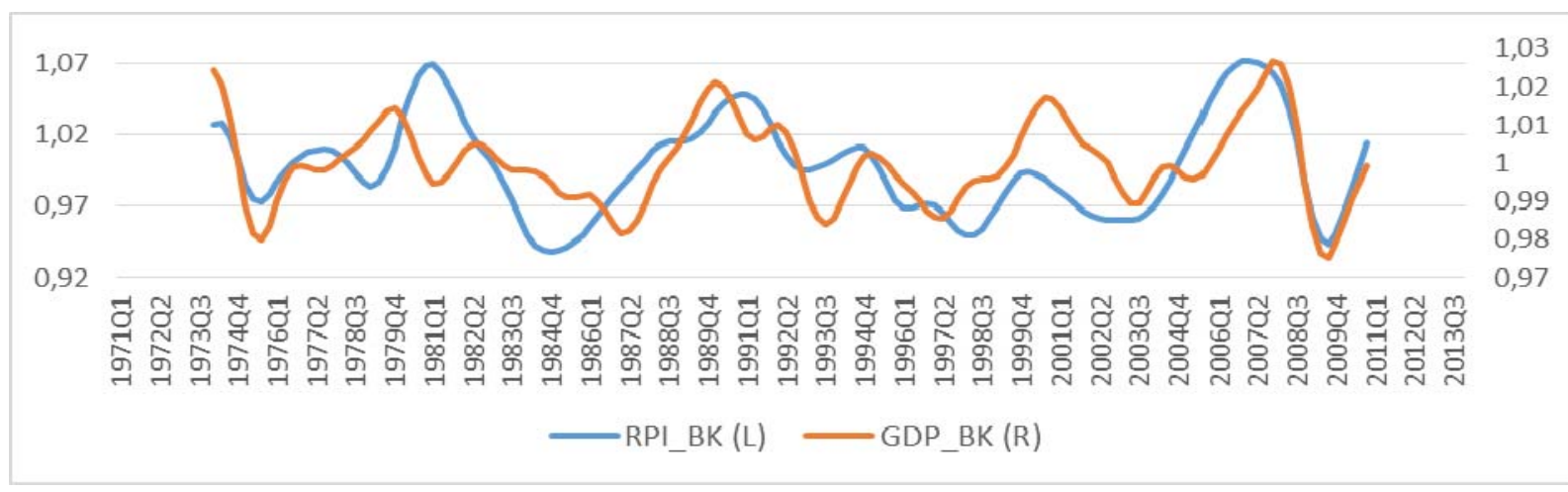

Fig. 2b. Housing market cycles and business cycles in France. Source: the author's own compilation.

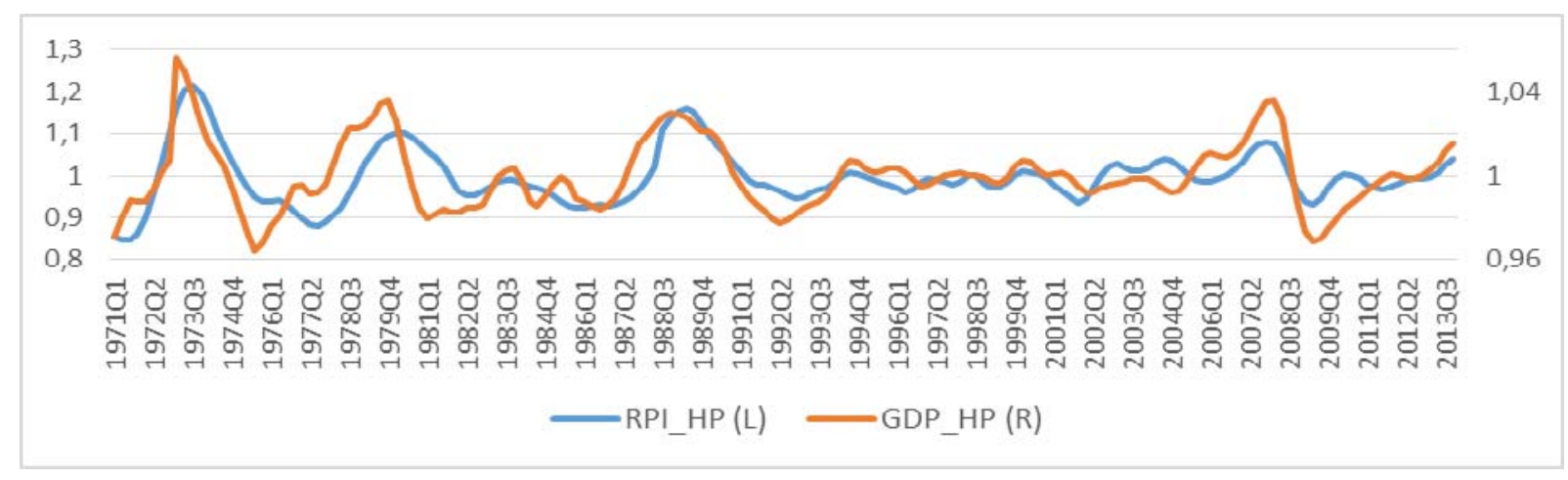

Fig. 3a. Housing market cycles and business cycles in the UK. Source: the author's own compilation.

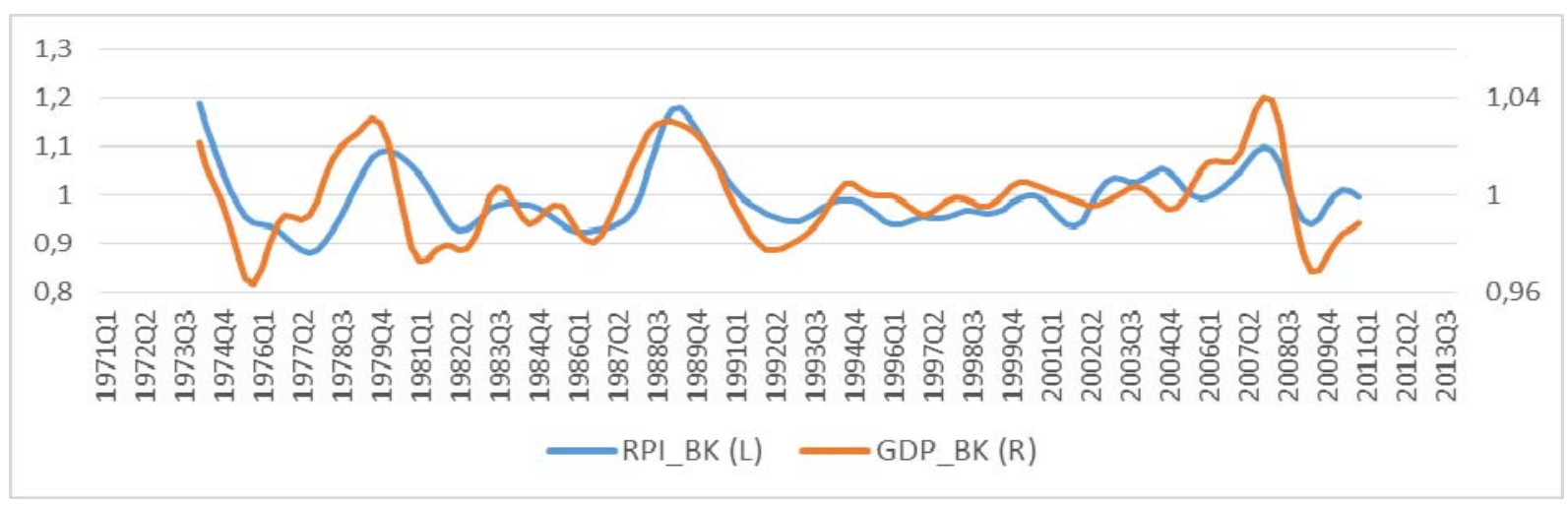

Fig. 3b. Housing market cycles and business cycles in the UK. Source: the author's own compilation.

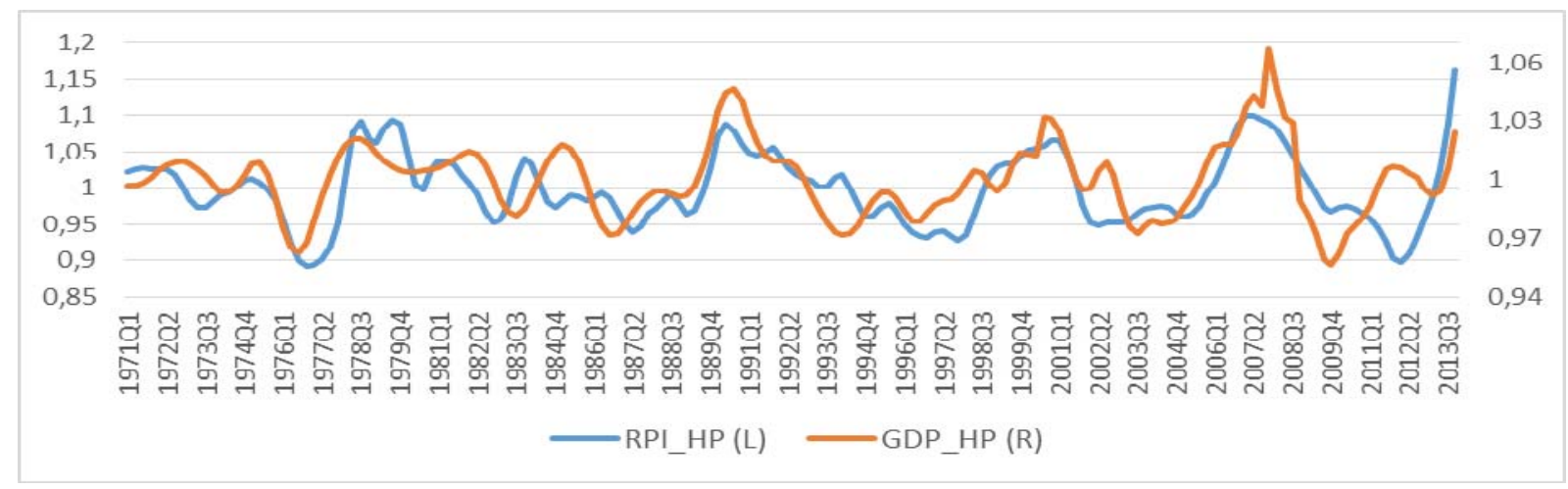

Fig. 4a. Housing market cycles and business cycles in Ireland. Source: the author's own compilation. 


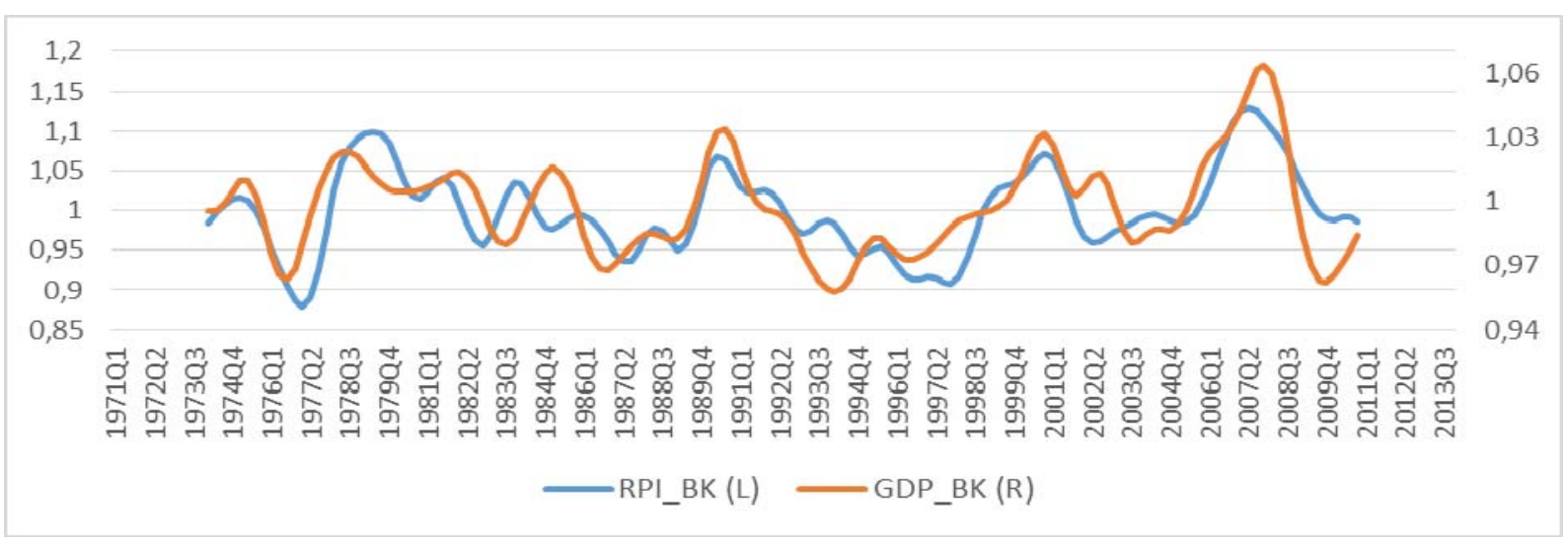

Fig. 4b. Housing market cycles and business cycles in Ireland. Source: the author's own compilation.

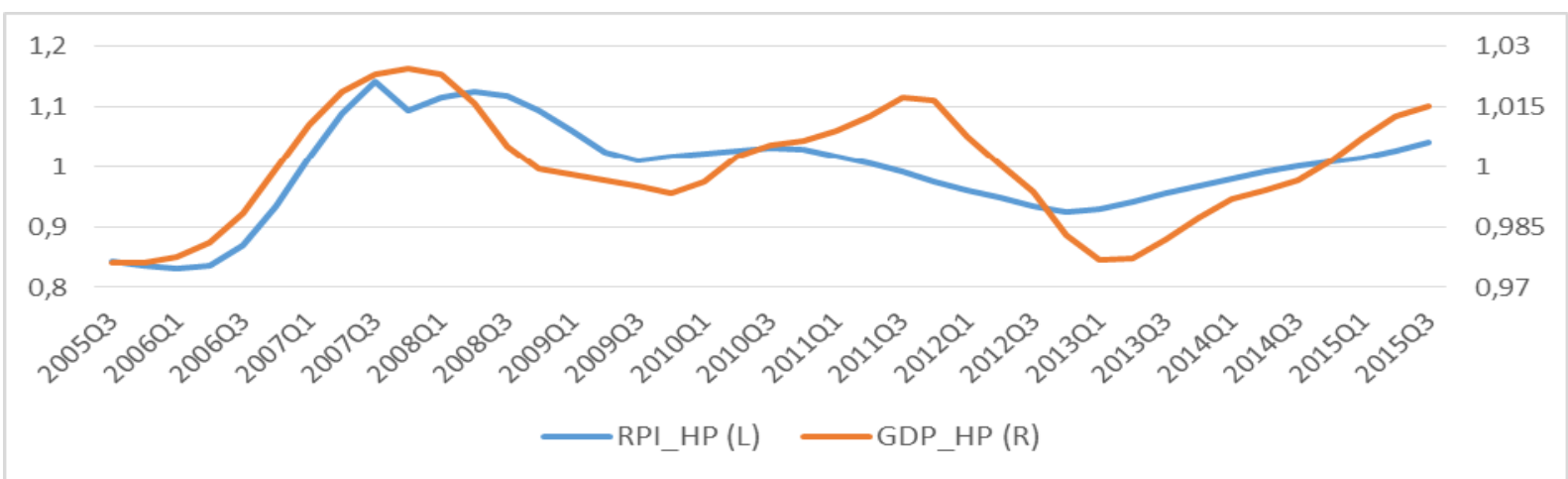

Fig. 5. Housing market cycles and business cycles in Poland. Source: the author's own compilation.

\section{Empirical results}

The isolated housing market and business cycles, in line with the modern definition, are presented as periodic oscillations of the variables relative to the long-term trend (the percentage deviation of the cyclical component isolated with the use of the HP filter and BK relative to the trend) (TROJANEK 2008 b). The course of the cycles in selected economies is presented in Figures 1-5. The results of the empirical analysis of the interdependence of the cycles in selected economies and the degree of their synchronisation are shown in Table 3.

Table 3

Basic statistics on concurrency of housing market cycles and business cycles

Economy Cross-correlation coefficients

Concordance index

(the time shift of the business cycle relative to the housing market cycle)

\begin{tabular}{|c|c|c|c|c|c|c|c|c|c|c|}
\hline \multicolumn{11}{|c|}{ Hodrick-Prescott filter } \\
\hline & $\mathrm{t}-4$ & $t-3$ & $t-2$ & $t-1$ & t0 & $t+1$ & $t+2$ & $t+3$ & $\mathrm{t}+4$ & \\
\hline Germany & 0,427 & 0,419 & 0,406 & 0,393 & 0,371 & 0,317 & 0,247 & 0,160 & 0,055 & $52,9 \%$ \\
\hline France & 0,167 & 0,315 & 0,449 & 0,546 & 0,596 & 0,607 & 0,582 & 0,529 & 0,455 & $66,9 \%$ \\
\hline UK & 0,510 & 0,617 & 0,695 & 0,726 & 0,692 & 0,564 & 0,385 & 0,173 & $-0,055$ & $76,7 \%$ \\
\hline Ireland & 0,481 & 0,551 & 0,603 & 0,636 & 0,645 & 0,577 & 0,481 & 0,369 & 0,248 & $60,5 \%$ \\
\hline
\end{tabular}




\begin{tabular}{|c|c|c|c|c|c|c|c|c|c|c|}
\hline Poland & 0,169 & 0,391 & 0,587 & 0,723 & 0,780 & 0,661 & 0,480 & 0,254 & 0,013 & $78,0 \%$ \\
\hline \multicolumn{11}{|c|}{ Baxter-King filter } \\
\hline & $t-4$ & $t-3$ & $t-2$ & $\mathrm{t}-1$ & to & $t+1$ & $t+2$ & $t+3$ & $t+4$ & \\
\hline Germany & 0,398 & 0,404 & 0,399 & 0,388 & 0,365 & 0,316 & 0,247 & 0,159 & 0,058 & $64,9 \%$ \\
\hline France & 0,207 & 0,323 & 0,437 & 0,531 & 0,587 & 0,588 & 0,554 & 0,496 & 0,425 & $70,3 \%$ \\
\hline UK & 0,569 & 0,638 & 0,682 & 0,688 & 0,644 & 0,511 & 0,340 & 0,144 & $-0,056$ & $75,0 \%$ \\
\hline Ireland & 0,576 & 0,673 & 0,738 & 0,764 & 0,745 & 0,684 & 0,588 & 0,471 & 0,343 & $71,6 \%$ \\
\hline
\end{tabular}

Source: the author's own compilation.

In most of the analysed economies, a significant correlation between the business cycle and the housing market cycle can be observed. With the exception of the German economy, the crosscorrelation coefficients exceed the level of 0.6. Apart from Poland, for which the period of analysis was significantly shorter, the isolated cycles were most strongly correlated in the case of the UK and Ireland. In most cases, the housing market cycle was concurrent with or had a one-quarter lag relative to the business cycle.

On the basis of concordance indices, it can also be noted that in at least $60 \%$ of the analysed time interval, business cycles and housing market cycles remained in the same phase of the cycle. Significantly higher concordance indices were recorded for Poland $(78 \%)$ and the UK $(76.7 \%$ for the cycles isolated on the basis of the Hodrick-Prescott filter, and $75 \%$ for the cycles isolated with the use of the Baxter-King filter).

\section{Conclusions}

The study confirms a significant similarity in the course of housing market cycles and business cycles in selected economies. Although the correlation between cycles is significant, it is not complete. This confirms the thesis that indicates that the course of housing market cycles is affected not only by macroeconomic determinants but also by "special forces within the real estate sector".

Differences in the level of synchronisation of housing market cycles and business cycles in the analysed economies should also be emphasised. Certain unique determinants of the functioning of national housing markets, not covered by the study, such as the ownership, quantitative and qualitative structure of housing stock, the system of financing of housing investments, as well as legal, institutional and cultural factors, can have an impact on the situation.

\section{References}

AKIMOV A., STEVENSON S., Young J., 2015, Synchronisation and commonalities in metropolitan housing market cycles, Urban Studies Vol. 52, Issue 9, pp. 1665-1682

Bandt O., Knetsch T., PeÑAlosa J., Zollino F., 2010, Housing Markets in Europe: A Macroeconomic Perspective, Springer Science \& Business Media.

BARRAS R., 1994, Property and Economic Cycle: Building Cycles Revised, Journal of Property Research, No 11, pp. 183-197.

BAXTER M., KING R.G., 1999, Measuring Business Cycles: Approximate Bandpass Filters, The Review of Economics and Statistics, 81(4), pp. 575-593.

BELSKY E., PRAKKEN J., 2004, Housing's Impact on Wealth Accumulation. Wealth Distribution and Consumer Spending. National Association of Realtors.

BRACKE P., 2013, How long do housing cycles last? A duration analysis for 19 OECD countries, Journal of Housing Economics Vol. 22, Issue 3, pp. 213-230.

Catte P., Girouard N., Price R., ANDRE C., 2004, Housing Markets, Wealth and the Business Cycle, OECD Economic Department Working Paper No. 394.

DOMAŃSKA A., SERWA D., 2014, Synchronizacja cykli koniunkturalnych a podatność gospodarek krajów Europy na skutki kryzysu gospodarczego 2008-2009 (Synchronisation of Business Cycles and Vulnerability 
of Economies of European Countries to the Effects of the Economic Crisis 2008-2009), Ekonomia nr 37, pp. 27-55

Ghent A., OwyAng M., 2009, Is Housing the Business Cycle? Evidence from U.S. Cities, Federal Reserve Bank of St. Louis Working Paper 2009-007B, St. Louis.

HODRICK R.J., PRESCOTT E.C. , 1997, Postwar U.S. Business Cycles: An Empirical Investigation, Journal of Money Credit and Banking, vol. 29, no. 1, pp. 1-16.

KONOPCZAK K., 2009, Analiza zbieżności cyklu koniunkturalnego gospodarki polskiej ze strefa euro na tle krajów Europy Środkowo-Wschodniej oraz państw członkowskich strefy, Raport na temat petnego uczestnictwa Rzeczypospolitej Polskiej w trzecim etapie Unii Gospodarczej $i$ Walutowej. Projekty badawcze (Analysis of the convergence of the business cycle of the Polish economy with the euro area compared to the countries of Central and Eastern Europe and the Member States, Report on the full membership of the Republic of Poland in the third stage of the Economic and Monetary Union. Research projects), Warszawa.

KUCHARSKA-STASIAK E., 2006, Nieruchomość w gospodarce rynkowej(Real Estate in Market Economy], PWN, Warszawa.

KUCHARSKA-STASIAK E. red. 2008, Cykle rynku nieruchomości a sektor bankowy (Property Cycles and the Banking Sector), Fundacja na Rzecz Kredytu Hipotecznego, Warszawa.

KUCHARSKA-STASIAK E., ZAŁĘCZNA M., ŻELAZOWSKI K., 2012, Wptyw procesu integracji Polski z Uniq Europejską na rozwój rynków nieruchomości (The Impact of Poland's Accession to the European Union on the Development of Real Estate Markets), Wyd. UŁ, Łódź.

LAMA R., DenIS S., 2014, Housing and Business Cycles: Is the UK Different from Other Advanced Economies?, IMF Country Report No. 14/234.

LEAMER E., 2007, Housing is the Business Cycle, NBER Working Paper 13428, National Bureau of Economic Research, Cambridge.

Lis P., 2015, Cykle mieszkaniowe. Rola rynku i państwa (Housing Market Cycles. The Role of the Market and the State), Wyd. UE w Poznaniu, Poznań.

MicKIEWICZ P., WeNCEL K., 2013, Godne życie dla wszystkich - wykluczenie spoteczne migrantów jako skutek złych warunków mieszkaniowych (A Decent Life for All - Social Exclusion of Immigrants as a Result of Poor Housing Conditions), Instytut Spraw Publicznych, Warszawa.

SKRZYPCZYŃSKI P., 2010, Metody spektralne w analizie cyklu koniunkturalnego gospodarki polskiej (Spectral Methods in Analysis of Business Cycle in the Polish Economy), NBP, Warszawa.

SOвCZYK M., 2000, Statystyka. Podstawy teoretyczne, przykłady - zadania (Statistics. Theoretical Basis, Examples and Exercises),Wyd. UMCS, Lublin.

TAKHTAMANOVA Y., SiERMinSKA E., 2008, The Effect of Wealth on Consumption Expenditures: Cross Country and Cross Socio-Demographic Group Comparisons, Ekonomia (Ekonomia. Rynek, Gospodarka, Społeczeństwo), Issue: 20, pp. 68-95.

TROJANEK R., 2008a, Wahania cen na rynku mieszkaniowym (Price Fluctuactions in the Housing Market), Wyd. AE w Poznaniu, Poznań.

TROJANEK R., 2008b, Determinanty wahan cen na rynku mieszkaniowym (Determinants of House Price Fluctuations), Studia i Materiały Towarzystwa Naukowego Nieruchomości - vol. 16 nr 4, Olsztyn, pp. 85-98.

UlRICHS M., BŁAŻEj M., JĘDRYCH J., 2014, Równolegty oraz wyprzedzający zagregowany wskaźnik koniunktury, zegar koniunktury. Identyfikacja mechanizmów i przebiegu cyklu koniunkturalnego dla Polski. Metodologia (Concurrent and Leading Aggregate Economic Sentiment Indicator, Business Cycle Clock. Identification of the Mechanisms and the Course of the Business Cycle for Poland. Methodology), GUS, Warszawa. 